\title{
Building networks among info pros
}

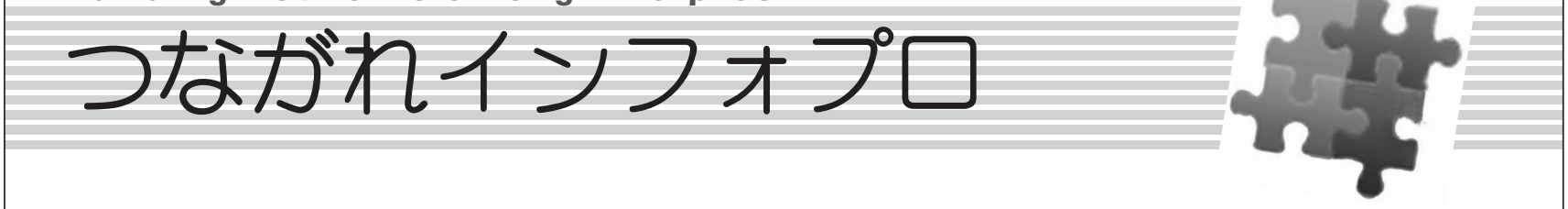

第 17 回

平野正明（株式会社住化技術情報センター 情報技術千葉チーム）

情報管理５7(11), 845-848, doi: 10.1241/johokanri.57.845 (http://dx.doi.org/10.1241/johokanri.57.845)

\section{日本 PLASDOC 協議会とは}

$\lceil P L A S D O C 」 は ， D e r w e n t$ 社（現Thomson Reuters 社）の化学分野の特許情報に対する索引システムCPI (Chemical Patents Index) の1つでAGDOC (農薬)， FARMDOC（医薬）に続いて創設されたポリマー（高 分子）分野に対する分類のことである11。

日本の化学会社の規模は欧米に比べると小さい。 個々では情報提供業者（プロデューサーやベンダー， 以下，ベンダー）に対し発言力は小さく，欧米企業 の意見が優先されがちである。しかし，各社が1つ となることで欧米の大企業に引けを取らない発言力 をもちうる。その考えのもとに生まれたのが日本 PLASDOC協議会（以下，JPA）である。

JPAの会則第1条にはこうある。「本会は，会員相互 の連絡を密にすることによって，会員の利益を守り， 且つポリマーに関する特許又は文献等の検索技術の 向上を図ることを目的とする」。JPAは，ポリマー関 連の情報調査に対し，会員間の交流による個人のス キルアップはもちろんのこと，ワーキングを通じ相 互協力し，個人ではなしえない諸問題の解決を図る ことを目的とする会である。事実，この理念に沿っ て，それまで聞き入れてもらえなかった数々の要求 を実現してきた。その主な要求としては，(1) 英文抄 録の質の向上と収録スピード (2) PLASDOC（現ポリ マーインデキシング) コードの改善 (3) 価格の妥当性， などがあげられる。それ以外にも，データベースの 機能改善や瑕疵の是正についても適宜要求を行って いる。これらはベンダーへの圧力という意味合いも あるが，何よりもベンダーと一体となり，より高品質，
高性能なものを作り上げていくというJPAに課せられ た使命である。

2014年現在，会員は25社で約半世紀の歴史の中， 企業の合従連衡や入れ替わりがあったものの発足当 時の会員社数を維持している。

\section{JPA 沿革}

JPAは，1966年，Derwent社のPLASDOCサービス の開始にあわせ18社からなるユーザー会が発足し，4 年後の1970年には化学系企業30社からなる協議会 として正式発足した。8年後の1978年に研修会がス タートし，現在もなお続いている。1985～1987年 には，高額なCPI利用料の日米欧間価格差解消に一 役買った。1990年代に入り，特許出願が爆発的に増 えPLASDOCコードではフォールスドロップが発生し ノイズが増え始めた。PLASDOCコードでは対応でき なくなったことから，抜本的な改善を目指し，1994 年にはPLASDOCコードからポリマーインデキシング コード (以下， PI）へと変更となった。JPAは，この PIの評価にも寄与した。また，2004年にはThomson Reuters社へ，DWPI (Derwent World Patents Index) に収録される中国特許の英文抄録に対し，質の向上 と収録スピードの改善要求を行っている。

このほか，1990年には，20周年記念誌『Polymer 一日本PLASDOC協議会20年のあゆみ一』（図1）, 2000年に30周年記念誌『Polymer一日本PLASDOC協 議会30年のあゆみ一』をそれぞれ発行した。2006年 に開設したWebサイトの会員専用サイトには，1993 年以降のワーキング全資料を掲載している。一般の 


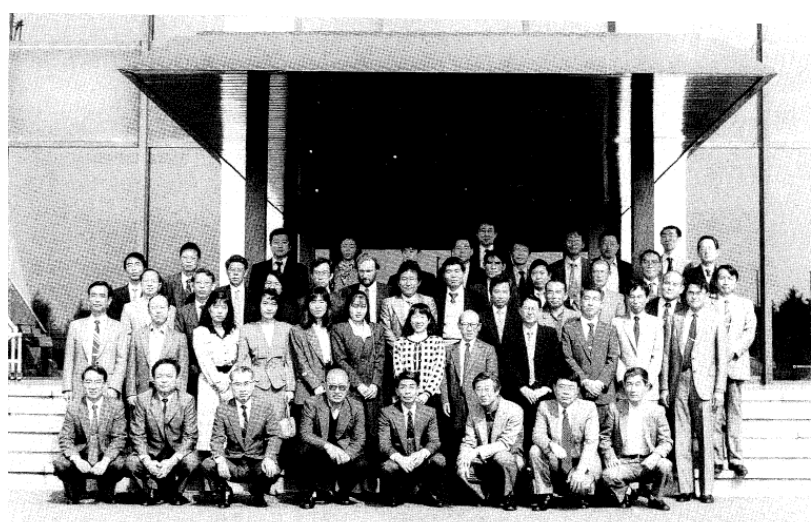

富士教育研修所での秋季研修会より

※20周年記念誌『Polymer』より抜粋

図1秋季研修会（1990年）

サイトには，現在進行中のワーキングテーマと，過 去のワーキングテーマを公開している。なお，入会 などの問い合わせもこのWebサイトから可能なので 興味のある方は，ぜひアクセスしていただきたい注1)。

40周年を迎えた2010年には，「審査側のサーチ，出 願側のサーチ」と題し，外部有識者による記念講演 を東京ディズニーリゾートにあるヒルトン東京ベイ で行った（図2）。2015年の今年は45周年を迎える。

\section{活動内容}

毎年3月には会員各社に向け，ワーキングテーマを 募集している。各メンバーからは1，2テーマの提案 があり，中には1人で3，4テーマを提案する人もいる。 提案されたテーマを5，6グループにグルーピングし， 活動テーマを確定する。グルーピングの段階で落と されるテーマもあるが，残してほしいと懇願される こともあり，テーマに対するメンバーの熱い思いを 感じる。

1つのグループは3〜6名で構成され（最少単位は3 名)，毎回の参加者は30名前後となる。

5月には総会を開催し，役員の改選を行っている。 役員は輪番制で毎年6名体制をとっている。2年の任 期で， 1 年目は副会長グループに属し，会長グループ を補佐する。2年目には会長グループに属し，年間行 事を総理する。一方，各ワーキンググループは，総

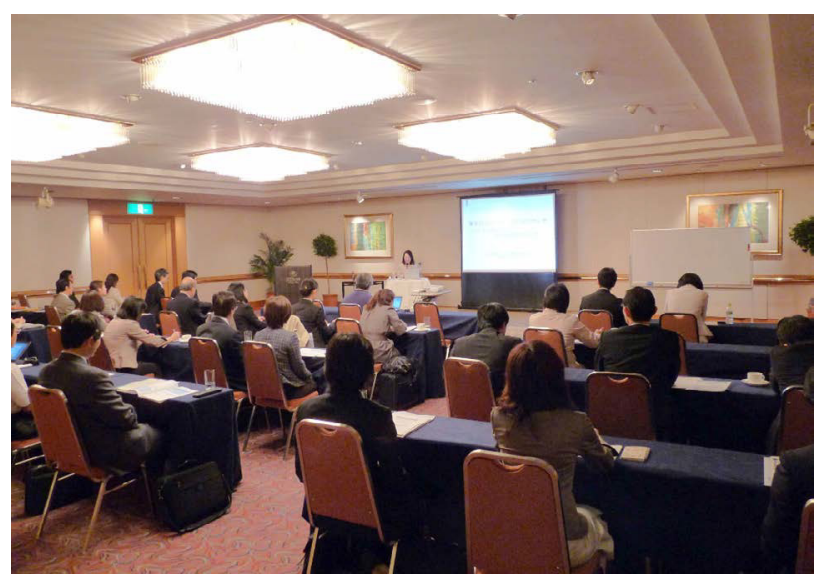

図2４0周年記念講演会の風景（ヒルトン東京ベイにて）

会の場でグループリーダーや会合のスケジュールを 決め，以降ワーキング活動がスタートする。また総 会開催時には，外部演者を招き，講演会を行っている。

5月からスタートして6か月のワーキング活動期間 を経て，各グループはその成果を11月の研修会で発 表する。前述したように，得られた成果物はJPAの会 員専用サイトに掲載される。発表資料はもちろんの こと，発表形式にするまでの生データもここに掲載 される（図3）。

発足当時，会名のとおり研究対象はもつぱらポリ マ一関連，すなわちPLASDOCコードをはじめとする CPIの研究が中心だった。もちろんポリマーといって も重合体だけではない。組成物，プロセス，成形，応用， 用途など幅広い。しかし，昨今では，各国特許庁の1 次情報データベースの充実化，中国，韓国，台湾な ど新興国・地域の台頭による出願件数の増加に伴う 数々のデータベースの出現，Thomson Reuters社の1 次情報とDWPIの2次情報を組み合わせたハイブリッ ドプラットフォームThomson Innovation，各国リー ガルステータスを収録するデータベース，分析・解 析ツール，概念検索など，研究対象は枚挙にいとま がないほど拡大している（表1）。

\section{インフォプロの将来}

2007年ごろ，ユビキタスなるキーワードがもては 


\section{日本PLASDOC協蓄会』P}

(Japan Plasdoc Association)

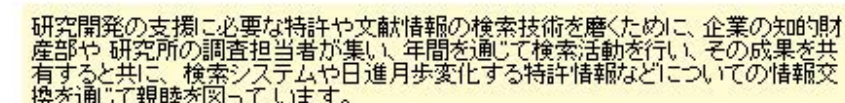

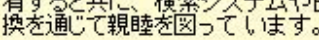

あなたち私たちの活動に参加して会社に貢諵ませ九か？

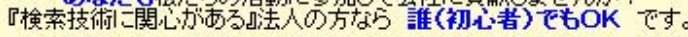

\begin{tabular}{|c|c|}
\hline サ仆内换 & Search 型悠会の恣料も挨索 \\
\hline
\end{tabular}

1 ホー片ュース $(2014 / 12 / 3)$

JPAの最近の動き、今後の予定などを䓡らせします。

2014年度研修会を11月27日(木) 28日(金)開催しました。会㽞専用ベージに资㪴を㑑

次捍栽中年す。

-関連リンク集のPLASDOC OB会へのリンク先を恋更しました。

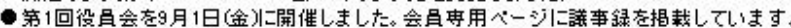

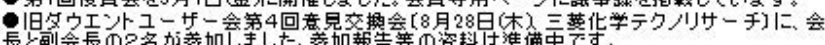

2014年庴の活動内客紹介のベージを更新しました。

- 新入会肙を㫷集しています。

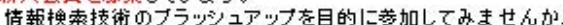

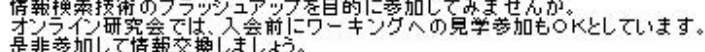

2 JPA|ついて(日本吾更 英吾医[English])を招介します。

日本PLASDOC協議会って何だ?

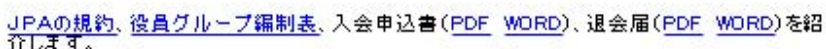

\section{3 活動内咅招介 $(2014 / 12 / 9)$ 更类}

2014年度の活動内客, JPA発足加らの垪究報告内客を紹介しています。

每年、客の䍃会でワーキンクテーマとクループを決め、秋の研修会で発表を行なっていま

す。

4 会㚗叀用ベージ $(2014 / 9 / 9)$ 更妾

図3 日本PLASDOC協議会のWebサイト

やされ，いつでもどこでもパソコンさえあれば情報 収集が可能となり，エンドユーザー自らがデータベー スを操作するWeb検索が一般化し，通信料の固定化 と相まって，気軽に情報を取得できる時代が到来し た。このような時代にプロフェッショナルサーチャー (インフォプロ）としてアドバンテージをどのように もち続けるかが課題とされ「サーチャーが消える日」 を想像した人も多いのではないだろうか。

あれから8年，情報担当者はどうなったのだろう？ かつての限られた情報ツールから必要情報だけを取 り出すことが主題とされた時代とは異なり，数多い データベースの中から適切なものを選択，テキスト マイニングによる分析思考力，一見価值のない大量 テキスト情報に要素を加えたビッグデータの解析， 可視化など，インフォプロ（サーチャー）に要求さ
れることは以前よりも増しているのではないだろう か。私たち情報担当者を取り巻く環境は，知的財産 情報だけでなく，あらゆる情報を対象に，いままで は見えていなかった情報を価値ある情報へと変える スキルが要求されていると考える。

さいでに

欧米企業からみれば，コンペティター（競合相手） と協調して活動するJPAのような組織が滑稽に見える か屯しれない。しかし，わかちあえるところは，敵 味方関係なく協力し合うさまは，まさに日本の文化 であり，強みだと感じる。

JPAは，研究開発の支援に必要な情報調査技術を 磨くため，企業の知的財産部や調査担当者が集まり， 年間を通して活動していくことによって，その成果 


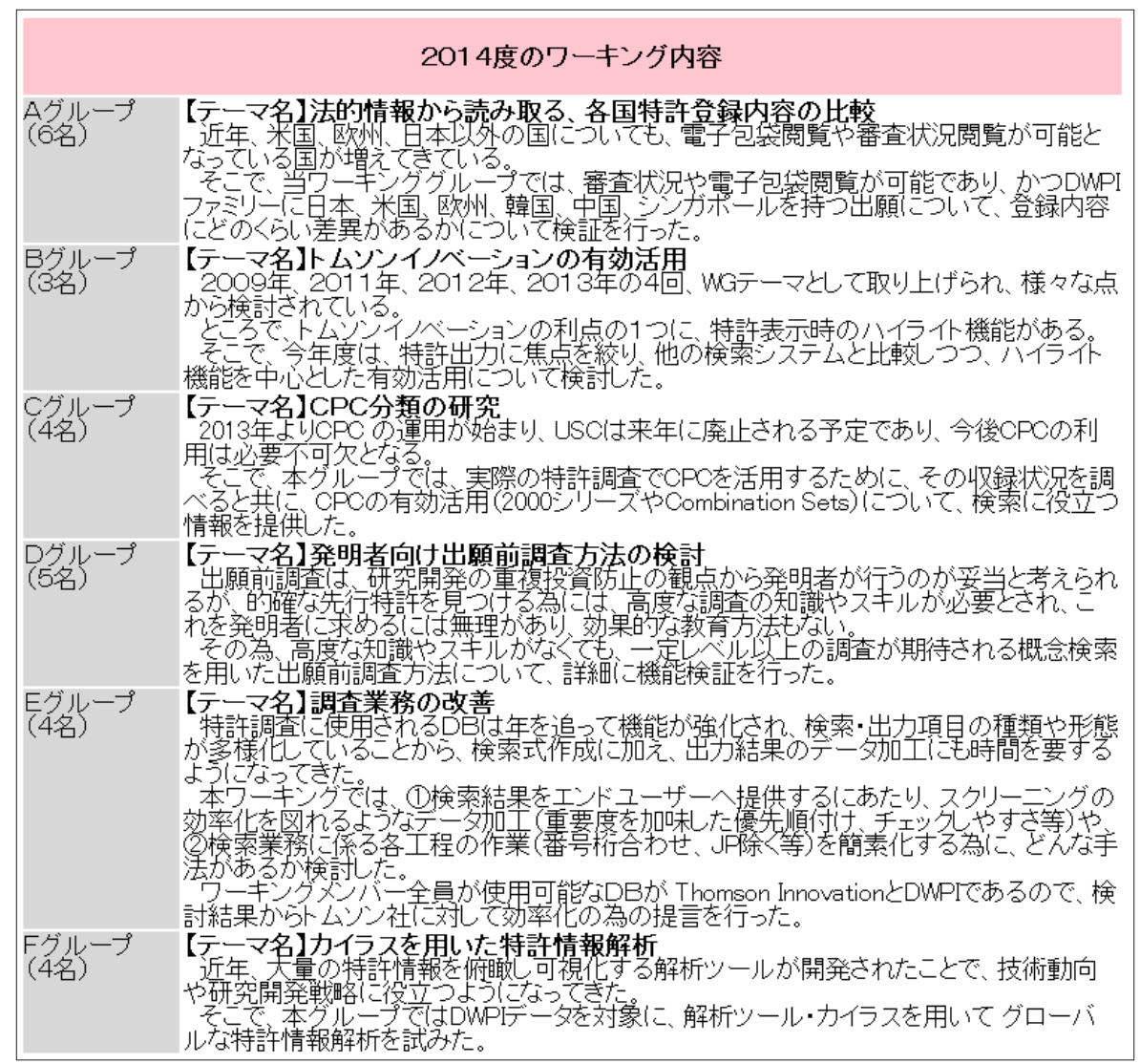

を共有している。また，検索システムや日進月歩で 変化している特許事情の情報交換などを通して親睦 を図っている。興味のある方は，ぜひ参加していた だきたい。

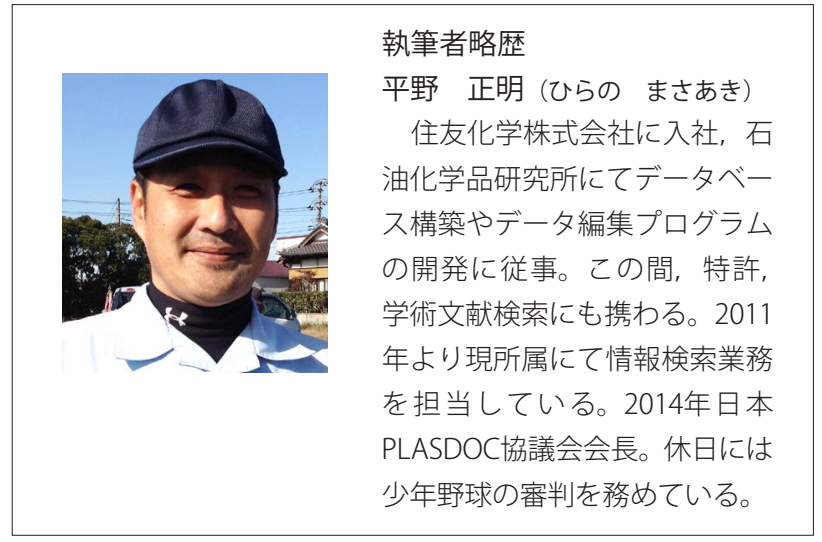

本文の注

注1）日本PLASDOC協議会. http://plasdoc.sakura.ne.jp/

参考文献

1）吉田文紀. Plasdocの解説. 高分子. 1966, vol. 15, no. 176, p. 952-956. 